\title{
A computational tool for directing Taxus spp. cell culture metabolism from growth to $\mathrm{Taxol}^{\circledR}$, a diterpene alkaloid, production

\author{
Khairiah Abd-Karim*, Radia Chibani and Ferda Mavituna
}

\author{
Address: School of Chemical Engineering and Analytical Science, The University of Manchester, Manchester, Sackville St, PO Box 88, M60 1QD, \\ UK \\ Email: Khairiah Abd-Karim* - k.abd-karim@postgrad.manchester.ac.uk \\ * Corresponding author
}

from BioSysBio 2007: Systems Biology, Bioinformatics and Synthetic Biology

Manchester, UK. II-13 January 2007

Published: 8 May 2007

BMC Systems Biology 2007, I(Suppl I):P47 doi: I0.1 I86/I752-0509-I-SI-P47

This abstract is available from: http://www.biomedcentral.com/I752-0509/I?issue=SI

(C) 2007 Abd-Karim et al; licensee BioMed Central Ltd.

\section{Background}

In this study, the computational metabolic flux analysis was used for batch cultures in order to study the metabolic flux shifts from growth to Taxol ${ }^{\circledR}$ production in Taxus (yew tree) cell suspension cultures. Taxol ${ }^{\circledR}$, a complex diterpene alkaloid, is approved by the FDA for the treatment of ovarian and breast cancer [1]. It was originally isolated from the bark of Taxus brevifolia. However, the bark contains very low concentrations of Taxol ${ }^{\circledR}$. Furthermore, since the extraction from the bark causes the death of the plant, it is not an environmentally acceptable route to production. Despite the current semi-synthetic method of commercial production, Taxol $^{\circledR}$ is still an expensive drug. Plant cell cultures therefore, can be a promising alternative for Taxol ${ }^{\circledR}$ production. Commercial use of the plant cell cultures for Taxol ${ }^{\circledast}$ production is nevertheless limited by the low or unstable productivity [2].

\section{Model reconstruction}

In order to find strategies to direct the Taxus spp. plant cell metabolism from primary to secondary product formation, we used the computational metabolic flux balancing approach. The in silico Taxus metabolism was reconstructed involving about 170 stoichiometrically balanced metabolic reactions in matrix formalism using the information from the literature and databases (top-down and bottom-up approach). Then, computational metabolic flux balancing method was used in order to obtain fluxes of all the metabolic reactions with linear programming and optimisation in GAMS environment (General Algebraic Modeling System). The objective function of optimisation was either the maximisation of the specific growth rate or the maximisation of the specific Taxol ${ }^{\circledR}$ production rate. The model allowed import in to the cell and excretion from the cell of certain important metabolites. Experimental values of nutrient uptake rates such as glucose, fructose and oxygen during the course of the batch culture were used as constraints in the mathematical model to give different sets of optimised flux distributions for different periods of the batch culture. A study of these flux distributions indicated the shifts in the metabolism during the batch culture.

\section{Results}

The computational specific growth rates were ten times higher than the experimental specific growth rates and the computed values of the specific Taxol ${ }^{\circledR}$ production were almost 5 times higher than the experimental ones. The computed carbon flux into the pentose phosphate pathway (PPP) for Taxol $^{\circledR}$ production was more important than that for growth. The PPP is the source for biosynthesis of the most important compounds involved either indirectly in Taxol ${ }^{\circledast}$ biosynthesis such as, aromatic amino acids or directly such as, phenylalanine, benzoyl-CoA and 
NADPH. A substantial amount of NADPH was needed during Taxol ${ }^{\circledast}$ biosynthesis and this could only be provided through the PPP. The experimental medium (control) contained both ammonia and nitrate as the nitrogen source. Using ammonia as the only source of nitrogen, the model indicated no change in the specific growth rate or Taxol $^{\oplus}$ production rate compared to the control. However, when nitrate was the only nitrogen source, the model predicted that the specific growth rate and Taxol ${ }^{\circledast}$ production rates were lower compared to the control.

\section{Conclusion}

In conclusion, using metabolic flux balancing, some strategies such as media formulation, precursor addition and genetic engineering targets can be identified in silico in order to direct the metabolism and increase the Taxol ${ }^{\circledast}$ yield.

\section{References}

I. Pezzuto J: Taxol production in plant cell culture comes of age. Nature Biotechnology 1996, 14: 1083.

2. Zhong JJ: Plant cell culture for production of paclitaxel and other taxanes. J Biosci Bioeng 2002, 94:591-599.
Publish with Biomed Central and every scientist can read your work free of charge

"BioMed Central will be the most significant development for disseminating the results of biomedical research in our lifetime. " Sir Paul Nurse, Cancer Research UK

Your research papers will be:

- available free of charge to the entire biomedical community

- peer reviewed and published immediately upon acceptance

- cited in PubMed and archived on PubMed Central

- yours - you keep the copyright

Submit your manuscript here:

http://www.biomedcentral.com/info/publishing_adv.asp 